\title{
Identification and effects of alleles of gene Vrd2 according to economically valuable attributes of wheat in conditions of South Steppe of Ukraine
}

V. Fait,

Doctor of Biology, Corresponding Member of NAASU

O. Pohrebniuk,

A. Stelmakh, Doctor of Biology, Professor, Academician of NAASU

Plant Breeding and Genetics Institute - National Center of Seed and Cultivar Investigations

The purpose. To identify recombinant-and-inbred lines of combination of crossing Orenburgskaya 48//Cappelle Desprez/2B Chinese Spring and to assess effects of alleles of gene Vrd2 on some economically valuable attributes. Methods. Temporal vernalization, genetic research, biological statistics. Results. Genotypes are identified of parent ingredients and recombinant-and-inbred lines of wheat Orenburgskaya 48//Cappelle Desprez/2B Chinese Spring for allelic state of gene Vrd2. Cappelle Desprez/2B Chinese Spring and 43 lines are the carrying agents of dominant allele of gene $\mathrm{Vrd} 2$, while grade Orenburgskaya 48 and 18 lines - of recessive vrd2. Effect of alleles of gene Vrd2 on separate economically valuable attributes is evaluated. Conclusions. In comparison with lines-carriers of recessive allele vrd2, presence of dominant allele Vrd2 results into decrease of winter- and frost resistance, cutting time to heading increase of weight of grains for an ear and grain yield.

Key words: wheat, alleles of gene Vrd2, vernalization, genotype, heading, yield, recombinant-and-inbred lines.

The requirement for a low temperature (vernalization) is one of the most important adaptive mechanisms that enables winter crops of mild climate to overwinter due to the delayed development at the vegetative stage in autumn and to form a yield under favorable environment of the spring and summer period of vegetation. A more durable need for vernalization causes slower development at the initial stages and the transition to the formation of a differentiated growing point and the rudiments of reproductive organs in these genotypes is observed much later [1]. The durable vernalization requirement before the transition to reproductive development determines both the level of plant resistance to negative temperatures [2] and the duration of the period before the decrease in this hardiness [3].

The winter bread wheat cultivars revealed significant differences in the duration of vernalization requirement from 15 to 60 or more days $[4,5,6]$. The cultivars of a particular region are characterized by a certain duration of vernalization requirement, which indicates the adaptive value of similar genotypes for certain growing environment. The modern cultivars of winter wheat in the Southern steppe of Ukraine (V-VII periodsof cultivar changing SGI-NCSCl, Odessa) are characterized by 30-40 days vernalization requirements [7], in contrast the old cultivars II-IV ones of a given region of cultivar Odes'ka 16 and Myronivska 808, which required vernalization near 50-60 days for the transition to generative development. This has become a result of widespread use during the 50s-60s years of the last century in the winter wheat breeding in the South of Ukraine of the semidwarf cultivars from Mexico, the USA, India, which are the sources of a number of useful traits that have a positive effect on the rate and intensity of biological and actual yield accumulation [8].

The tendency to reduce the vernalization requirement is also observed even in cultivars of the central part of the Ukrainian forest-steppe [9]. Among the cultivars of MIW named after V.M. Remeslo for already $76 \%$ stocks $30-40$ days vernalization is enough for transition to generative development. And only $24 \%$ ones head 
after 50-60 days vernalization. However, in the Czech Republic after 2000, a significant shift was observed in the direction of cultivars breeding with a more durable vernalization. [10]

Differences in the duration of vernalization requirement affect the heading date, drought tolerance, winter hardiness, frost resistance, the weigth of grains per head and yield [11, 12, 13, 14]. In the south of Ukraine, the reduced vernalization requirement contributes to a reliable increase in grain yield, but leads to a decrease in winter hardiness and frost resistance [15].

In winter bread wheat three genes were found: $V r d 1, V r d 2$ and $V r d 3$ with varying expressiveness controlling the differences in the duration of vernalization requirement [16]. The Vrd1 gene is located on chromosome $4 \mathrm{~A}$, the gene $\mathrm{Vrd} 2$ - on $5 \mathrm{D}$, and $\mathrm{Vrd} 3$ - on one of chromosomes $1 \mathrm{~A}$ or $6 \mathrm{~A}$ or $4 \mathrm{~B}$. [17]. The triple recessive $\operatorname{Vrd}$ genotype is characterized by the duration of vernalization requirement from 55 to more than 60 days, the presence of the dominant Vrd1 gene reduces it to 25-35 days, and Vrd2 or Vrd3 to 35-45 days [18]. The use of the dominant $V r d 2$ allele was recommended for the creation of new frost resistant cultivars for the Southern steppe of Ukraine [19], since vrd1Vrd2vrd3 the genotype has higher winter hardiness and frost resistant and don't differ significantly by yield from the most common at that time in production Vrd1vrd2vrd3 and Vrd1Vrd2vrd3 genotypes [20].

Aim of the research is to identify the recombinant inbred lines of the Orenburgskaya 48 / Cappelle Desprez / 2B Chinese Spring cross and evaluate the effects of the Vrd2 gene alleles on some economically valuable traits.

Research methods. The research objects are 64 recombinant-inbred lines (RIL) $F_{\sharp \text { from }}$ the crossing of the cultivar Orenburgskaya 48 to substituted in 2B chromosome Capelle Desprez / 2B Chinese Spring line. The cultivar Orenburgskaya 48 and the Capelle Desprez / 2B Chinese Spring line differed in the field environment in terms of plant height, heading date, the number of spikel ets in the main head, glume hairing and others [20]. Of the more than 190 RILs created by the SSD (single seed descent), 64 lines were selected for which all possible combinations of these differences between parental stoks were presented.

The genetic analysis by the genes Vrd of cultivar Orenburgskaya 48 and the Capelle Desprez / 2B Chinese Spring line was carried out according to the methodology developed in the SGI-NCSCI [16]. The testers were near isogenic lines of Erythrospermum 604-Vrd1, Erythrospermum 604-Vrd2, and Erythrospermum 604 and Mironivs'ka 808 cultivars (both $v r d 1$ vrd2). To identify the Vrd genotypes of 64 RILs, the 5-days seedlings of each line were vernalized during 40 and 30 days in a CST-1 chamber at $2^{\circ} \mathrm{C}$ and illuminated 12 hours at 3000 lux, but the cultivar Orenburgskaya 48 and the Capelle-Desprez / 2B Chinese Spring line did during 50 days additionally. After vernalization the seed lings were planted on April 26 in 5-liter vessels ten plants per each and were grown in a vegetation plots area under the environmet of a natural day length (from 14 hours to 20 minutes to 15 hours 46 minutes) day. To determine duration of the period to heading (DPH) heading dates of individual plants were recorded.

To evaluate the effects of Vrd2 gene alleles seeds of RILs and parental stocks were sown in the fall of 2011-2013 (on October 22, 12 and 4, respectively) in plot areas of $3 \mathrm{~m}^{2} 500$ grains per $1 \mathrm{~m}^{2}$ in the experimental field of the department of general and molecular genetics of the Institute. The experiment was repeated for three times. The seedlings frost resistance was estimated at $-12 \stackrel{\circ}{ } \mathrm{C}$ [22], and the vegetative phase did at $-13 \ldots-14^{\circ} \mathrm{C}$ [23]. For the latter case, in the second decade of January or in the first decade of March (depending on the presence of snow cover), 75-90 plants of each genotype were taken from the field (25-30 plants per each repetition). Winter hardiness was determined in the field by counting the number of plants at the end of October and those overwintered in the spring. During vegetation, heading date was recorded in the presence of $75 \%$ headed plants on the plot, which was transformed (from May 1) to duration of the period to heading (DPH). After harvesting in 30 plants of each line (10 per repetitions) the height of plants (HP), productive tillering (PT), namber of grains per head (NGH) and weight of grains per head (WGP), weight of 1000 grains (WTG), weight of grain and straw of the plant were registered to calculate harvest index (HI), as well as the number of productive tillers per unit area (NPT) and grain yield (GY).

Meteorological parameters during the research period included the whole range of possible adverse environmental factors that are common in the Ukrainian Steppe. This allowed to evaluate objectively the source material for the average adaptivity under those environment and also made it possible to differentiate on al- 
ternative alleles of the Vrd2 gene in parental stocks and RILs of winter bread wheat for a set of economically valuable traits.

Statistical data processing was carried out using generally accepted methods for calculating mean, $\mathrm{t}$ and $\chi^{2}$ criteria and variance analysis [24].

Results of research and discussion. The parental cultivar Orenburgskaya 48 and the substituted on 2B chromosome Capelle Desprez / 2B Chinese Spring line differ in the duration of vernalization requirement (Fig. 1). For plants of the Capelle Desprez / 2B Chinese Spring line there is inherent a 30-days vernalization requirement. The heading of this line plants after given duration of vernalization was observed at 49.0 and 48.2 days in 2010 and 2011 , respectively. A further increase in the duration of the previous vernalization to 40 or 50 days did not lead to a significant reduction of the period to heading in the Capelle Desprez / 2B Chinese Spring line. On the contrary plants of the cultivar Orenburgskaya 48, required a vernalization not less than 50 days for a generative development. Plants of this cultivar have headed after 50 -days vernalization on 59,6 and 69,2 days in 2010 and 2011, respectively. With the vernalization duration of 40 and 30 days plants of the cultivar Orenburgskaya 48 were in the tillering phase up to the end of the experiment (97-98 days). Only in 2010 after 40-days vernalization we observed heading in six from ten plants at 62-88 days.

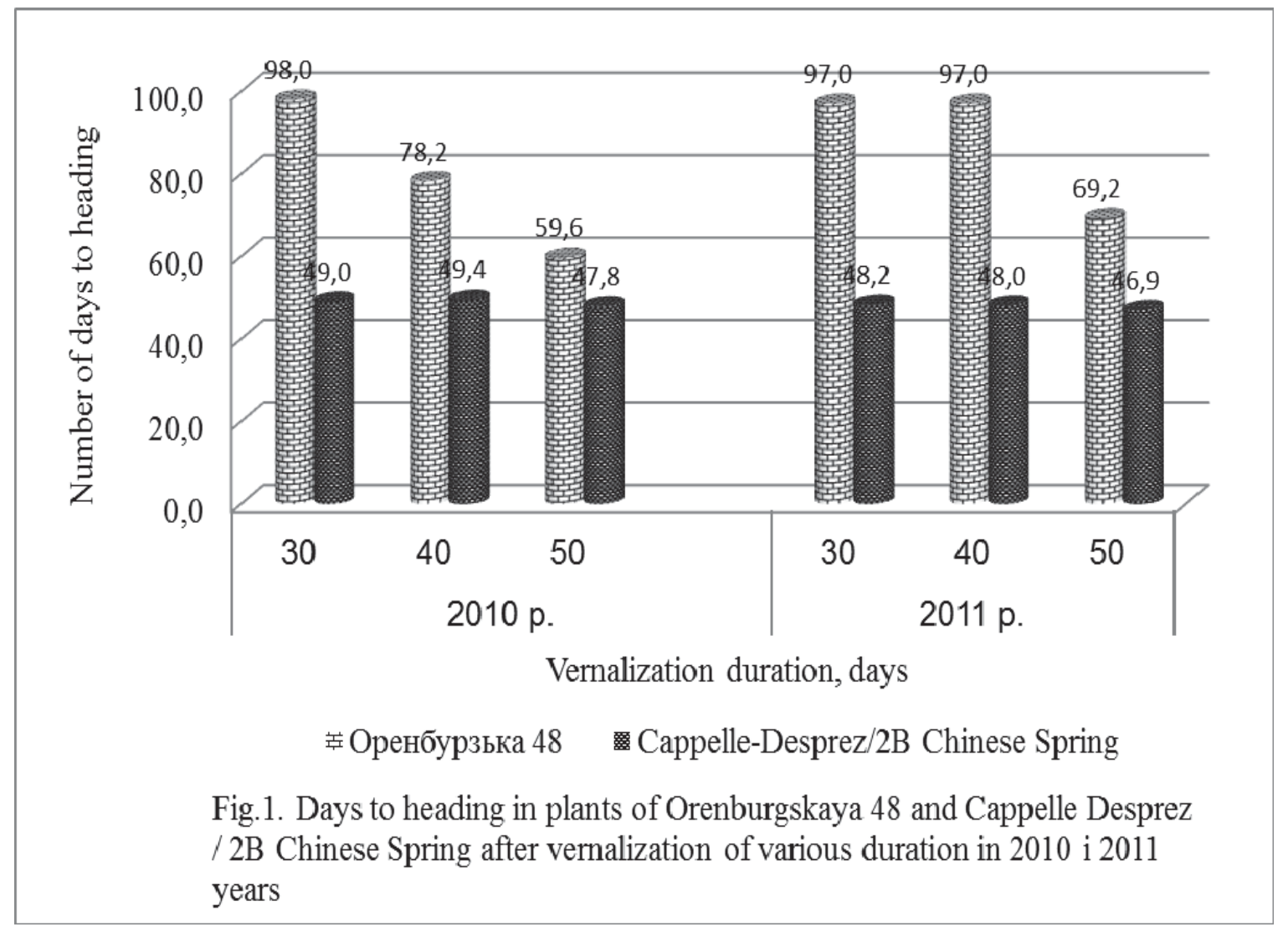

In 2012 among $F_{\text {z }}$ plants of the population got from cross of cultivar Orenburgskaya 48 to the Cappelle Desprez / 2B Chinese Spring line, 53 headed plants and 20 non-headed plants were detected after 40 days of vernalization. This relationship corresponded to the theoretically with the theoretically expected 54,75 : $18,25$, showing the differences in the alleles of one gene ( $3: 1)$. The criterion for compliance $\chi^{2} 3: 1$ is 0,77 . In 2016, a segregation in $F$ for this combination also consisted of 56 headed plants to 13 non-headed plants and corresponded to monogenic one $\left(\chi^{2} 3: 1=1,40\right)$ suggesting a monogenic difference between parental stocks.

According to the results of the genetic analysis, it can be concluded that the Capelle Desprez / 2B Chinese Spring line is the carrier of the dominant $V r d 2$ gene (Table 1). This conclusion was based on the presence of monogenic differences in segregation on headed and non-headed plants after 40-days vernalization

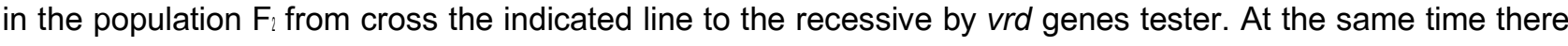
was an absence of segregation (all plants were headed) in cross the Capelle Desprez / 2B Chinese Spring 
line to the dominant by $V r d 2$ gene tester and the presence of digenic differences in crosses to dominant by Vrd1 or Vrd3 genes tester.

1. Segregations to the headed and non-headed plants in $F_{2}$ populations from crosses of the cultivar Orenburgskaya 48 and the Capelle Desprez / 2B Chinese Spring line to the Vrd gene testers after 40day vernalization

\begin{tabular}{|l|l|l|l|l|l|}
\hline \multirow{2}{*}{ Stocks } & \multirow{2}{*}{ Year } & \multicolumn{4}{|l|}{ Testers } \\
\cline { 3 - 6 } & & Recessive & Vrd1 & Vrd2 & Vrd3 \\
\hline Capelle Desprez /2B & 2012 & $63: 12^{*}$ & $59: 7^{* *}$ & $77: 0$ & $66: 4^{* *}$ \\
Chinese Spring & 2013 & $56: 12^{*}$ & $69: 8^{* *}$ & $73: 0$ & $71: 4^{* *}$ \\
& 2015 & $67: 15^{*}$ & $72: 8^{* *}$ & $77: 0$ & $72: 3^{* *}$ \\
\hline Orenburgskaya 48 & 2016 & $65: 13^{*}$ & $88: 3^{* *}$ & - & - \\
\hline & 2012 & $0: 36$ & $24: 38$ & $52: 13^{*}$ & $39: 30$ \\
& 2013 & $0: 54$ & $43: 11^{*}$ & $65: 20^{*}$ & $49: 17^{*}$ \\
& 2016 & - & $60: 19^{*}$ & $49: 18^{*}$ & $52: 28$ \\
\hline
\end{tabular}

Note. $\left.{ }^{*} \chi^{2} 3\right\} 4,84 ;{ }^{* *} \chi^{2} 15: 1<3,84$

Unlike the Capelle Desprez / 2B Chinese Spring line in the cross of the cultivar Orenburgskaya 48 to the recessive by $V r d$ genes tester, the segregation was not revealed after 40-day vernalization. All plants were in the tillering phase. However, in $F_{2}$ populations when crossed the specified cultivar to monogenically dominant $V r d 1$ or $V r d 2$ or $V r d 3$ genes testers we revealed segregations into headed or non-headed plants, though which was not always coincided to the theoretical expectation for the digenic differences of parents. Nevertheless, the very fact of the segregation on plants that headed or did not head after 40-days vernalization in our opinion, can testify to the presence of genetic differences of the cultivar Orenburgskaya 48 and testers of the gene Vrd1 in 2012 or Vrd3 in 2012 and 2016. Thus, the Orenburgskaya 48 has a recessive genotype by the $V r d$ genes.

Since the differences in vernalization requirement between the cultivar Orenburgskaya 48 (50 days) and the Capelle Desprez / 2B Chinese Spring line (30 days) are only due to allelic differences in the Vrd2 gene ( $v r d 2$ or $V r d 2$, respectively), and the use of 40- and 30-days vernalization can identify the genotypes of recombinant-inbred lines for the Vrd2 gene. The presence of the dominant allele of the Vrd2 gene in the genotype of the lines will contribute to early heading (reduction of period to heading), and the allele $v r d 2$, on the contrary, will hold back the development that phenotypically is manifested in increasing the duration of the period to heading in lines with this allele [20]. RILs significantly differed in the duration of the period to heading (Table 2). Thus, the scope of the variation of the period to the RILs heading was from 47,2 (line 58) up to 88,7 days (line 139) at the 40-days vernalization and 57,6-91,5 days after vernalization of 30 days, respectively, lines 58 and 177. In both variants of the vernalization duration of, non-headed lines were observed. As the criterion for the attribution of the RIL to carriers of the dominant or recessive allele of the Vrd2 gene was the use of the heading date (62 days) at the 40-day vernalization of the first plant of the cultivar Orenburgskaya 48 carrier of the recessive allele $v r d 2$. Therefore, lines $58,50,10,96,44,60,17,33,23,45,131$, $105,24,92,28,148,71,97,59,74,57,164,117,98,165,121,80,112,166,151,89,146,90,185,177$, as well as the Cappelle Desprez / 2B Chinese Spring line after 30- and 40-day vernalization, may be characterized as carriers of the $\mathrm{Vrd} 2$ gene. At the same time, in the lines that did not head at 30-day but they headed at 40-day vernalization for 51.8-57.2 days (lines $94,13,39,40,29,56,5,14$ ) were also attributed to the carriers of the dominant $\operatorname{Vrd} 2$ gene. 


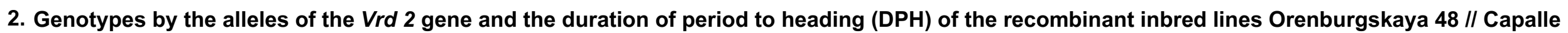
Desprez / 2B Chinese Spring after 30- and 40-days vernalizations, days

\begin{tabular}{|c|c|c|c|c|c|c|c|c|c|c|c|}
\hline Line & Genotype & 40 days & 30 days & Line & Genotype & 40 days & 30 days & Line & Genotype & 40 days & 30 days \\
\hline 58 & Vrd 2 & $47,2 \pm 0,80$ & $57,6 \pm 2,16$ & 164 & Vrd 2 & $60,8 \pm 1,24$ & $65,5 \pm 2,25$ & 36 & vrd2 & $59,8 \pm 2,43$ & $\mathrm{n}$ \\
\hline 50 & Vrd 2 & $48,2 \pm 0,20$ & $54,3 \pm 1,11$ & 117 & Vrd 2 & $61,2 \pm 0,80$ & $84,5 \pm 7,80$ & 111 & vrd2 & $61,0 \pm 1,58$ & $\mathrm{n}$ \\
\hline 10 & Vrd 2 & $49,0 \pm 1,26$ & $52,0 \pm 0,89$ & 98 & Vrd 2 & $62,0 \pm 0,95$ & $81,4 \pm 6,96$ & 77 & vrd2 & $62,0 \pm 5,10$ & $\mathrm{n}$ \\
\hline 96 & Vrd 2 & $49,2 \pm 1,20$ & $55,8 \pm 2,13$ & 165 & Vrd 2 & $62,0 \pm 1,14$ & $84,2 \pm 5,64$ & 109 & vrd2 & $62,8 \pm 3,20$ & $\mathrm{n}$ \\
\hline$C D^{*}$ & Vrd 2 & $49,4 \pm 0,51$ & $49,0 \pm 1,76$ & 121 & Vrd 2 & $64,0 \pm 1,61$ & $75,2 \pm 1,96$ & 65 & vrd2 & $63,4 \pm 2,62$ & $\mathrm{n}$ \\
\hline 44 & Vrd 2 & $50,2 \pm 1,39$ & $58,6 \pm 1,72$ & 80 & Vrd 2 & $64,6 \pm 2,62$ & $71,6 \pm 0,98$ & 124 & vrd2 & $63,5 \pm 2,40$ & $\mathrm{n}$ \\
\hline 60 & Vrd 2 & $51,6 \pm 1,54$ & $58,6 \pm 2,16$ & 112 & Vrd 2 & $64,8 \pm 3,66$ & $91,8 \pm 6,20$ & 133 & vrd2 & $65,7 \pm 1,90$ & $\mathrm{n}$ \\
\hline 17 & Vrd 2 & $53,6 \pm 1,17$ & $82,3 \pm 10,27$ & 166 & Vrd 2 & $65,6 \pm 1,25$ & $74,5 \pm 1,50$ & 35 & vrd2 & $66,0 \pm 1,05$ & $\mathrm{n}$ \\
\hline 33 & Vrd 2 & $53,8 \pm 0,20$ & $72,6 \pm 6,76$ & 151 & Vrd 2 & $65,7 \pm 0,67$ & $73,3 \pm 0,85$ & 118 & vrd2 & $66,0 \pm 0,58$ & $\mathrm{n}$ \\
\hline 23 & Vrd 2 & $54,0 \pm 0,63$ & $63,0 \pm 2,08$ & 89 & Vrd 2 & $66,0 \pm 1,58$ & $84,8 \pm 8,14$ & 143 & vrd2 & $66,0 \pm 1,00$ & $\mathrm{n}$ \\
\hline 45 & Vrd 2 & $54,8 \pm 2,84$ & $65,8 \pm 8,07$ & 146 & Vrd 2 & $67,0 \pm 1,00$ & $82,8 \pm 8,83$ & 38 & vrd2 & $68,0 \pm 0,70$ & $\mathrm{n}$ \\
\hline 131 & Vrd 2 & $54,8 \pm 0,86$ & $67,2 \pm 8,12$ & 90 & Vrd 2 & $67,7 \pm 1,33$ & $93,6 \pm 4,40$ & 140 & vrd2 & $69,3 \pm 1,31$ & $\mathrm{n}$ \\
\hline 105 & Vrd 2 & $55,0 \pm 0,89$ & $58,0 \pm 0,91$ & 185 & Vrd 2 & $68,0 \pm 0,45$ & $86,5 \pm 6,64$ & 108 & vrd2 & $70,0 \pm 3,03$ & $\mathrm{n}$ \\
\hline 24 & Vrd 2 & $55,4 \pm 0,98$ & $60,2 \pm 0,97$ & 177 & Vrd 2 & $72,5 \pm 5,50$ & $91,5 \pm 6,50$ & 122 & vrd2 & $75,5 \pm 7,50$ & $\mathrm{n}$ \\
\hline 92 & Vrd 2 & $55,8 \pm 1,80$ & $75,8 \pm 7,07$ & 94 & Vrd 2 & $51,8 \pm 0,58$ & $\mathrm{n}^{* *}$ & Or.* & vrd2 & $78,2 \pm 8,14$ & $\mathrm{n}$ \\
\hline 28 & Vrd 2 & $56,6 \pm 1,29$ & $61,0 \pm 0,89$ & 13 & Vrd 2 & $52,0 \pm 0,77$ & $\mathrm{n}$ & 139 & vrd2 & $88,7 \pm 9,33$ & $\mathrm{n}$ \\
\hline 148 & Vrd 2 & $57,0 \pm 1,10$ & $66,2 \pm 2,22$ & 39 & Vrd 2 & $54,5 \pm 1,19$ & $\mathrm{n}$ & 152 & vrd2 & $\mathrm{n}$ & $\mathrm{n}$ \\
\hline 71 & Vrd 2 & $57,0 \pm 0,58$ & $92,2 \pm 5,80$ & 40 & Vrd 2 & $56,0 \pm 0,95$ & $\mathrm{n}$ & 153 & vrd2 & $\mathrm{n}$ & $\mathrm{n}$ \\
\hline 97 & Vrd 2 & $57,2 \pm 0,49$ & $67,0 \pm 2,10$ & 29 & Vrd 2 & $56,2 \pm 1,32$ & $\mathrm{n}$ & 161 & vrd2 & $\mathrm{n}$ & $\mathrm{n}$ \\
\hline 59 & Vrd 2 & $58,0 \pm 1,22$ & $82,2 \pm 6,46$ & 56 & Vrd 2 & $56,8 \pm 1,55$ & $n$ & 136 & $v r d 2 / V r d 2$ & $73,4 \pm 10,2$ & $\mathrm{n}$ \\
\hline 74 & Vrd 2 & $58,4 \pm 1,94$ & $76,5 \pm 3,50$ & 5 & Vrd 2 & $57,0 \pm 2,26$ & $\mathrm{n}$ & 31 & $v r d 2 / V r d 2$ & $78,6 \pm 8,4$ & $\mathrm{n}$ \\
\hline 57 & Vrd 2 & $59,0 \pm 0,41$ & $73,0 \pm 8,38$ & 14 & Vrd 2 & $57,2 \pm 1,16$ & $\mathrm{n}$ & 181 & $v r d 2 / N r d 2$ & $90,5 \pm 7,5$ & $\mathrm{n}$ \\
\hline
\end{tabular}


Other lines of this group are $36,111,77,109,65,124,133,35,118,143,38,140,108,122,139,152$, 153,161 , which headed on 59.8-88,7 or which did not head at all, can be described as carriers of the recessive allele $v$ rd2.

Most plants of the studied lines headed within three days interval. At the same time, the variation of duration the period to heading of individual plants of the lines 181, 31, and 136 amounted from 30 to 39 days. On that basis, these 3 lines were characterized as possible populations for the both alleles of the Vrd2 gene (Vrd 2 / vrd2). Thus, the identified Vrd genotypes 64 RILs F/ of cross Orenburgskaya 48 / Cappelle Desprez / 2B Chinese Spring: 43 lines are carriers of dominant Vrd2, 18 lines - vrd2, and 3 lines - the possible populations by alleles of the given gene.

The variance analysis results according to various economically valuable traits in the studied set (wich we evaluated in 2011-2013) indicated with high probability a significant role (Table 3) of genetic differences between the sub-sets of the carriesr of the alleles $V r d 2$ or $v r d 2$ for the four traits: winter hardiness $(P<0,01)$, duration the period to heading, the weight of grain per head, grain yield (all at $P<0,05$ ).

3. Results of two-factor (year and genotype) variance analysis of the traits differences in studied RILs Orenburgskaya 48 // Cappelle Desprez / 2B Chinese Spring for the alleles of the gene Vrd2, 2011-2013.

\begin{tabular}{|l|l|l|l|l|}
\hline Trait & Year & Genotype & Interaction & $\begin{array}{l}\text { Random fac- } \\
\text { tors }\end{array}$ \\
\hline df & 2 & 1 & 2 & 180 \\
Wint. & $4,5^{* * *}$ & $1,4^{* *}$ & 0,4 & 0,2 \\
DPH & $1664,8^{* * *}$ & $26,6^{*}$ & 0,7 & 5,1 \\
HP & $18326^{* * *}$ & 7 & 59 & 74 \\
PT & $0,644^{* * *}$ & 0,001 & 0,127 & 0,091 \\
NGH & $2370,4^{* * *}$ & 33,4 & 3,9 & 10,4 \\
WGH & $5,415^{* * *}$ & $0,090^{*}$ & 0,037 & 0,019 \\
WTG & $381,9^{* * *}$ & 11,5 & 7,3 & 8,8 \\
NPT & $664887^{* * *}$ & 293 & 3485 & 3288 \\
HI & $1,33^{* * *}$ & 0,02 & 0,01 & 0,01 \\
GY & $0,026^{* * *}$ & $0,015^{*}$ & 0,001 & 0,003 \\
\hline
\end{tabular}

Notes: ${ }^{*}$ - Reliable at $\mathrm{P} \leq 0,05 ;{ }^{* *}$ - at $\mathrm{P} \leq 0,01$; ${ }^{* * *}$ - at $\mathrm{P} \leq 0,001$.

The presence in the genotype of RIL of the dominant allele $\mathrm{Vrd} 2$ significantly reduced winter hardiness by $8 \%$, shortened the duration the period to heading by 0,9 days, increased the weight of head grain by $0,049 \mathrm{~g}$ comparing to the lines carrying the recessive allele $v r d 2$ (Table 4 ). The grain yield of RILcarriers of the $V r d 2$ allele was $0,336 \mathrm{~kg} / \mathrm{m}^{2}$ and exceeded on $0,020 \mathrm{~kg} / \mathrm{m}^{2}$ of the carriers of $\mathrm{vrd} 2(0,316$ $\mathrm{kg} / \mathrm{m}^{2}$ ). By other traits differences of the RILs subsets were not significant, although there was some tendency to increase the number of grains per head, the weight of thousand grains, and the harvest index in lines with the dominant allele Vrd2. 
4. Average values of economically valuable traits in groups of Orenburgskaya 48 // Cappelle Desprez / 2B Chinese Spring RILs differed by alleles of the Vrd2 gene

\begin{tabular}{|c|c|c|c|c|c|}
\hline \multicolumn{2}{|l|}{ Trait } & Vrd2 & vrd2 & $F_{\text {aik }}$ & HIP $_{0,05}$ \\
\hline \multicolumn{2}{|c|}{ Winter hardiness $\%$} & 76,0 & 84,0 & 6,20 & 1,2 \\
\hline \multirow{6}{*}{ 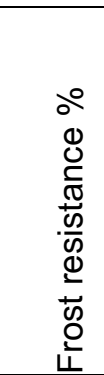 } & January $2011,-14^{\circ} \mathrm{C}$ & 28,3 & 39,0 & 1,11 & \\
\hline & January $2013,-14^{\circ} \mathrm{C}$ & 54,6 & 70,3 & 1,51 & \\
\hline & March 2011, -13 & 43,2 & 56,7 & 3,16 & \\
\hline & March $2012,-13^{\circ} \mathrm{C}$ & 80,8 & 90,5 & 5,97 & 1,8 \\
\hline & Sidlings $2012,-12^{\circ} \mathrm{C}$ & 13,4 & 21,2 & 1,74 & \\
\hline & Sidlings $2013,-12^{\circ} \mathrm{C}$ & 9,1 & 14,1 & 2,47 & \\
\hline \multicolumn{2}{|c|}{$\mathrm{DPH}$, days } & 15,6 & 16,5 & 5,20 & 0,7 \\
\hline \multicolumn{2}{|c|}{$\mathrm{HP}, \mathrm{cm}$} & 109 & 109 & 0,10 & \\
\hline \multicolumn{2}{|l|}{ PT, t. } & 1,7 & 1,7 & 0,02 & \\
\hline \multicolumn{2}{|c|}{$\mathrm{NGH}, \mathrm{g}$. } & 26,7 & 25,8 & 3,20 & \\
\hline \multicolumn{2}{|c|}{ WGH, g } & 0,940 & 0,891 & 4,72 & 0,043 \\
\hline \multicolumn{2}{|c|}{ WTG, $g$} & 32,7 & 32,2 & 1,30 & \\
\hline \multicolumn{2}{|c|}{$\mathrm{NPT}, \mathrm{p} . / \mathrm{m}^{2}$} & 432 & 429 & 0,09 & \\
\hline \multicolumn{2}{|l|}{$\mathrm{HI}$} & 0,50 & 0,47 & 2,66 & \\
\hline \multicolumn{2}{|c|}{$\mathrm{GY}, \mathrm{kg} / \mathrm{m}^{2}$} & 0,336 & 0,316 & 4,94 & 0,015 \\
\hline
\end{tabular}

Note: $F_{\text {比 }}=3.84$ at $P \leq 0.05$

Artificial freezing in the phase of sprouting and tillering did not reveal the benefits of one or another allele of the $V r d 2$ gene in cold resistance, with the exception of freezing at $-13^{\circ} \mathrm{C}$ in early March 2012 , when lines of $v r d 2$ genotype were higher frost resistant than such of $\operatorname{Vrd} 2$ genotype.

\section{Conclusions}

Genotypes of 64 RILs F9 Orenburgskaya 48 // Cappelle Desprez / 2B Chinese Spring were identified, as carriers of dominant or recessive alleles on $V r d 2$ gene. The presence of the dominant $V r d 2$ allele in the RILs genotypes led to a decrease in winter hardiness, frost resistance, to shortening of the period to heading and to an increase in the weight of grain per head and grain yield compared with the linescarryings of the recessive allele $v r d 2$.

\section{References}

1. Prasil I.T. Relationships among vernalization shoot apex development and frost tolerance in wheat/I.T. Prasil, P. Prasilova, K. Pankova//Annals of Botany. - 2004. - V. 94. - P. 413 - 418.

2. Prasil I.T. The relationship between vernalization requirement and frost tolerance in substitution lines of wheat/I.T. Prasil, P. Prasilova, K. Pankova//Biologia Plantarum. - 2005. - V. 49(2). - P. 195 200.

3. Mahfoozi S. Influence of vernalization and photoperiod responses on cold hardiness in winter cereals/S. Mahfoozi, A.E. Limin, D.B. Fowler//Crop Science. - 2001. — № 41. - P. 1006 - 1011.

4. Долгушин Д.А. Мировая коллекция пшениц на фоне яровизации/Д.А. Долгушин. - М.: Сельхозгиз, 1935. - $110 \mathrm{c}$.

5. Vernalization studies with Pacific Northwest wheat/D.M. Baloch, R.S. Karow, E. Marx et al.//Agron. J. - 2003. - V. 95. - P. $1201-1208$.

6. Уразалиев Р.А. Селекционно-генетические исследования зерновых культур в Казахстане/Р.А. Уразалиев, А.С. Абсаттарова//Вестн. ВОГиС. - 2005. - Т. 9, № 3. - С. $415-422$. 
7. Стельмах А.Ф. Разнообразие генотипов современных сортов озимой мягкой пшеницыпопотребности в яровизации и фоточувствительности/А.Ф. Стельмах, В.И. Файт/Молекулярная и прикладная генетика. -2011 . - Т. 12. - С. $15-18$.

8. Литвиненко Н.А. Влияние ярового компонента на формирование биологического и хозяйственного урожая у ярово-озимых гибридов пшеницы/Н.А. Литвиненко, Р.В. Соломонов//Scientific J. «ScienceRise». - 2015. - № 3/1(8). - C. 87 - 94.

9. Булавка Н.В. Яровизационная потребность современных сортов пшеницы мягкой озимой (Triticum aestivum L.)/H.В. Булавка, Л.Н. Голик//Сортовивчення та охорона прав на сорти рослин.2007. - № 6. - C. $54-59$.

10. Petr J. Changes in requirements on vernalization of winter wheat varieties in the Czechrepublic in 1950 - 2000/J. Petr, F. Hnilicka//Rostl. Vyroba. - 2002. - V. 48, № 4. -P. 148 - 153.

11. Tas $B$. Determination of vernalization responses in some winter wheat varieties grown in temperate regions/B. Tas, N. Celik//Asian J. of Plant Sciences. - 2008. — № 7. - P. $607-610$.

12. Gorafi Y.S.A. Alteration of wheat vernalization requirement by alien chromosome-mediated transposition of MITE/Y.S.A. Gorafi, A.E. Eltayeb, H. Tsujimoto//Breeding Science. - 2016. - V. 66. P. $181-190$.

13. Košner J. Vernalisation response of some winter wheat cultivars (Triticum aestivum L.)/J. Košner, K. Pánková//Czech J. Genet. Plant Breed. - 2002. - № 38 (3 - 4). - P. 97 - 103.

14. Есимбекова М.А. Система эффрективного управления признаковой коллекцией пшеницы «озимость-яровость» в условиях юговостока Казахстана/М.А. Есимбекова//Вестн. КазНУ.-Серия экологическая. - 2014. - № 2 (41). - С. 193 - 198.

15. Файт B.І. Морозостійкість і урожайність окремих сортів озимої пшениці/В.І. Файт//Вісн. аграр. науки. - 2005. - № 11. - С. $25-29$.

16. Chromosomal location of genes for vernalization requirement duration $(\mathrm{Vrd})$ in winter bread wheat/V.I. Fayt, L.K. Symonenko, N.V. Mokanu et al.//Russian J. of genetics. - 2007. - V. 43, № 2. P. $143-148$.

17. ДСТУ 7970 - 2015. Пшениця озима. Метод визначення морозостійкості через проморожування в рулонах/С. Гаврилов, В. Долгополова, В. І ванова, В. Кириченко, В. Петренкова, Н. Рябчун, П. Феоктістов, О. Четверик, Г. Хірна. -Введ. $2017-01-01$.

18. Методологічніпринципи оцінки озимої пшениці на терморезистентність в умовахпівдня України/П.О. Феоктістов, С.В. Гаврилов, А.К. Ляшок та ін. - К.: Вид. центр НАУ, 2006. - 36 с.

19. Рокицкий П.Ф. Биологическая статистика/П.Ф. Рокицкий. -М.: Колос, 1973. - 327 с. 